\title{
THE IMPACT OF REVOKING TRADE RESTRICTION ON THAILAND TOWARDS THE PRODUCTIVITY OF INDONESIA'S RICE DURING THE ERA OF ASEAN ECONOMIC COMMUNITY
}

\author{
Wisnujati Nugrahini Susantinah* \\ Post-graduate student, University of Brawijaya, Malang \& \\ Lecturer, University Of Wijaya Kusuma Surabaya, Indonesia \\ Nuhfil Hanani, Budi Setiawan, Syafrial, Lecturers \\ University of Brawijaya, Malang, Indonesia \\ *E-mail: wisnujatinugrahini@gmail.com
}

\begin{abstract}
The establishment of the ASEAN Economic Community are due to a number of reasons, namely the financial crisis in 1997 to 1998 . Western countries that are unsympathetic to negotiation, instigated to establish a new trade group on the Southeast Asia region. Furthermore, the competition between China and Japan to become the regional leader in Asia, led both countries to seek regional partnerships with other countries within the ASEAN jurisdiction. There is also the concern regarding the rapid economic growth in China and India, as well as the proliferation of preferential trade agreements.
\end{abstract}

\section{KEY WORDS}

ASEAN, economic community, trade restriction, simulation.

There are four concerns that are of focus for the AEC in 2015, which can be used by Indonesia as a momentum. Firstly, countries in the Southeast Asian region will be under a unified region of markets and production bases. Secondly, the AEC will be established as an economic area with a high rate competition, requiring policies such as competition policy, consumer protection, Intellectual Property Rights (IPR), taxation, and E-Commerce. Third, the AEC will be a region with an equally developed economy, with priority on Small and Medium Enterprises (SMEs). The competitiveness and dynamism of SMEs will be enhanced by facilitating their access to up-to-date information, market conditions, human resource development in terms of capacity building, finance, and technology. Fourth and final, the $A E C$ will be fully integrated into the global economy through a system in order to improve coordination of the member states. Based on the ASEAN Economic Blueprint, the AEC is urgently required to minimize the gap between ASEAN countries in terms of economic growth by increasing the dependency of the member states within the establishment. The AEC can develop a meta-national concept within the food supply chain sector and produce a single trading bloc that can handle and negotiate with exporters and importers from nonASEAN regions (Ario Baskoro, 2015).

\section{METHODS OF RESEARCH}

This research uses the Statistical Analysis System (SAS) software, in order to perform the simulation analysis to later built a statistical model. The model built is a simultaneous equation consisting of seven (7) structural models and two (2) identities. The data that are used in this research are collected from assortments of Time series data from Food Agriculture Organization (FAO) spanning from 1980 to 2013.

Structural equations are representations of endogenous variables and exogenous variables. The model built will produce the sign and the value of the parameter estimator in accordance to the economic theory. 
This research is divided into three (3) blocs; firstly, the domestic rice market bloc (Indonesia); secondly, the ASEAN bloc Market and lastly, the global market bloc. The endogenous variables consist of APB RB QIN PB DK DK PITA MTH MUSIC MKIS, and the exogenous variables consist of PPUK PBL APBL RBL IN PND PTH ERTH KU T T ERI PUSA RIN MUSAL MTHL P JAG RUSA RTH DKPITAL PKIS ERKIS.

The structural equation consists of:

$$
\begin{aligned}
& A P B=a+b 1 \text { * PB }+b 2 \text { * PPUK + b3 * KUT + b } 4 \text { * PJAG + b } 5 \text { *APBL +e } \\
& R B=a+b 1 * P B+b 2 \text { *PPUK + b } 3 \text { *RBL }+e \\
& P B=a+1 * P J A G+b 1 * P N D+b 2 * P B L+e \\
& \text { DKPITA }=b 1 \text { *PB }+b 2 * \text { IN }+b 3 * \text { DKPITAL }+e \\
& \mathrm{MTH}=\mathrm{b} 1{ }^{*} \mathrm{PTH}+\mathrm{b} 2{ }^{*} \mathrm{RTHH}+\mathrm{b} 3{ }^{*} \mathrm{ERTH}+\mathrm{b} 4{ }^{*} \mathrm{MTHL}+\mathrm{e} \\
& \text { MUSA }=b 2 \text { * ERI + b } 2 \text { *PUSA + b } 3 \text { *RUSA + b } 4 \text { * MKIS + b } 5 \text { * MUSAL + e } \\
& \text { MKIS }=a+b 1 * \text { PKISA + b2 *RIN + b } 3{ }^{*} \text { ERKIS }+e
\end{aligned}
$$

The identity equation consists of:

$$
\begin{gathered}
D K=D K P I T A * P N D \\
\text { QIN }=A P B * R B
\end{gathered}
$$

Where:

APB = Rice farmland;

$\mathrm{RB}=$ Productivity;

$P B=$ Price of rice;

QIN = Production of rice;

PPUK = Fertilizer price;

KUT = Agricultural credit;

PJAG = Price of corn;

$\mathrm{T}=$ Interest rate;

DK = Rice Demand;

IN = Income;

MIN = Indonesia's rice import;

QIN = Production;

$\mathrm{ERI}=$ Exchange rate of Indonesia;

$\mathrm{PW}=$ Global rice;

DKPITA = Rice per capita demand;

$\mathrm{RIN}=$ The value of Indonesian trade restriction;

DEER = The value of American trade restriction;

$\mathrm{RTH}=$ The value of Thailand trade restriction.

\section{RESULTS OF STUDY}

Prior to conducting the simulation analysis, it is necessary to conduct the analysis of model validation by looking at the value of the proportion of the bias (UM) the proportion of regression $\left(U_{R}\right)$, the proportion of distribution $(U c)$, and Theils' statistic for Inequality coefficient $\left(U_{\text {theil }}\right)$, its value can be seen in the following table:

Table 1 - Validation of Indonesian Rice Trade Performance Model

\begin{tabular}{|c|c|c|c|c|c|c|}
\hline No & Variables & $\mathrm{U}$ Theil & $\mathrm{U}^{\mathrm{M}}$ & $\mathrm{U}^{\mathrm{S}}$ & $\mathrm{U}^{\mathrm{c}}$ & Information \\
\hline 1 & APB & 0.0115 & 0.00 & 0.01 & 0.99 & Area of Harvest Land (Hectar) \\
2 & RB & 0.0079 & 0.02 & 0.02 & 0.96 & Productivity (Ton / Hectar) \\
3 & QIN & 0.0125 & 0.01 & 0.02 & 0.97 & Production (Tons) \\
4 & PB & 0.2669 & 0.28 & 0.57 & 0.15 & Price of Rice (Dollar) \\
5 & DK & 0.0167 & 0.01 & 0.00 & 0.99 & Request of Indonesian Rice (Tons) \\
6 & DKPITA & 0.0169 & 0.01 & 0.00 & 0.99 & Rice Demand Per Capita (Tons) \\
7 & MTH & 0.1272 & 0.14 & 0.08 & 0.78 & Import From Thailand (Tons) \\
8 & MUSA & 0.1310 & 0.56 & 0.10 & 0.35 & Import From America (Tons) \\
9 & MKIS & 0.0959 & 0.00 & 0.05 & 0.95 & Import From Pakistan (Tons) \\
\hline
\end{tabular}

Source: Processed FAO's Data. 
It is mandatory that the analysis observes the value of the proportion of the bias (UM), the proportion of regression $\left(U_{R}\right)$ the proportion of distribution $\left(U_{D)}\right.$ and also statistical Theils Inequality coefficient $(U)$. The analysis can be used to evaluate the model's ability to clicking simulation analysis Forecasting (ex ante simullation) If the data shows RMSE, RMSPE and U Theils small as well as the value of $R^{2}$ the greater the model predictions the better. Theils coefficient value $(U)$ ranges between 1 and 0 , if $U=0$ then the estimation is closer to perfection.

Table 2 - Basic Value of Indonesian Rice Economic Forecasting

\begin{tabular}{|c|c|c|c|c|c|}
\hline \multirow{2}{*}{ No } & \multirow{2}{*}{ Variables } & \multicolumn{2}{|c|}{ Simulation Results } & \multirow{2}{*}{ Deviation } & Information \\
\cline { 3 - 4 } & & Actual Mean & Predicted Mean & & \\
\hline 1 & APB & 11278.0 & 11276.9 & 0.00 & Area of Harvest Land (Hectar) \\
2 & RB & 4.3970 & 4.4069 & -0.22 & Productivity (Ton / Hectar) \\
3 & QIN & 50048.4 & 50147.4 & -0.00 & Production (Tons) \\
4 & PB & 16.1694 & 11.2315 & 0.30 & Price of Rice (Dollar) \\
5 & DK & 33963.4 & 34047.8 & 0.24 & Request of Indonesian Rice (Tons) \\
6 & DKPITA & 0.000170 & 0.000171 & 0.01 & Rice Demand Per Capita (Tons) \\
7 & MTH & 6209.9 & 5621.1 & 9.48 & Import From Thailand (Tons) \\
8 & MUSA & 2803.5 & 3423.0 & -31.9 & Import From America (Tons) \\
9 & MKIS & 1941.4 & 1941.4 & 0.01 & Import From Pakistan (Tons) \\
\hline
\end{tabular}

Source: Processed FAO's Data.

The result of the simulation shows, the actual value and the prediction value, if the comparison of predictive value is not much different from the actual value, in which in this research it ranges from 0.00 to 31.9. The largest is MUSA (Import from America) variable value of 31.9 , but the average devaluation value or deviation 6.02 is relatively small, thus it means that the prediction value can be used as the base value of the next simulation implementation.

Table 3 - Simulation on the Elimination of Trade Restrictions on Thailand $(\mathrm{RTH}=0)$

\begin{tabular}{|c|c|c|c|c|c|c|}
\hline \multirow{2}{*}{ No } & \multirow{2}{*}{ Variables } & \multicolumn{2}{|c|}{ Simulation Results } & \multicolumn{2}{|c|}{ Change } & \multirow{2}{*}{ Information } \\
\cline { 3 - 6 } & & Data Base & Simulation & Unit & Percentage & Area of Harvest Land (Hectar) \\
\hline 1 & APB & 11276.9 & 11690.1 & -413.2 & -3.66 & Productivity (Ton / Hectar) \\
2 & RB & 4.4069 & 4.3973 & 0.01 & 0.22 & Production (Tons) \\
3 & QIN & 50147.4 & 51957.9 & 1.810 .5 & -3.61 & Price of Rice (Dollar) \\
4 & PB & 11.2315 & 16.2597 & -5.0282 & -44.77 & Request of Indonesian Rice (Tons) \\
5 & DK & 34047.8 & 33947.8 & 100 & 0.29 & Rice Demand Per Capita (Tons) \\
6 & KPITA & 0.000171 & 0.000170 & 0.00 & 0.00 & Import From Thailand (Tons) \\
7 & MTH & 5621.1 & 6244.2 & -623.1 & -11.08 & Import From America (Tons) \\
8 & MUSA & 3423.0 & 2762.0 & 661 & 19.31 & Import From Pakistan (Tons) \\
9 & MKIS & 1941.4 & 1941.4 & 0.00 & 0.00 & \\
\hline
\end{tabular}

Source: Processed FAO's Data.

The result of the simulation analysis on the elimination of trade restrictions on Thailand $(\mathrm{RTH}=0)$ shows that there is a change in the use of I UAS crops in Indonesia, which there is a decrease of up to 413 hectares per year, down 3.66 percent. This is because there is a tendency if trade restriction is abolished within the AEC then Indonesian government would prefer to import rice, however Indonesia does not import rice from Thailand. It imports its rice from Vietnam; as a result the use of land dedicated for harvest in Indonesia is declining. In addition, there is a trend of narrowing harvested land in Indonesia due to its function converted into non-agricultural land. From this simulation, it can be seen that the number of rice imported by Indonesian from Thailand is reduced amounting to 623.1 tons compared to import from Vietnam. The price of Thailand's rice is higher than that of Vietnam, in 2035 amounted to 2282.62 dollars per ton, compared to the price of Vietnam rice which is 886.2 dollars per ton cheaper. 
Table 4 - Implementation of Single Har on the Environment of ASEAN Economic Community PTH = PB

\begin{tabular}{|c|c|c|c|c|c|c|}
\hline \multirow{2}{*}{ No } & \multirow{2}{*}{ Variables } & \multicolumn{2}{|c|}{ Simulation Results } & \multicolumn{2}{|c|}{ Change } & \multirow{2}{*}{ Information } \\
\cline { 3 - 5 } & & Data Base & Simulation & Unit & Percentage & Area of Harvest Land (Hectar) \\
\hline 1 & APB & 11276.9 & 11690.1 & -413.2 & -3.66 & Productivity (Ton / Hectar) \\
2 & RB & 4.4069 & 4.3973 & -51.95 & 0.22 & Production (Tons) \\
3 & QIN & 50147.4 & 51957.9 & -1.810 .5 & -3.61 & Price of Rice (Dollar) \\
4 & PB & 11.2315 & 16.2597 & -5.03 & -44.77 & Request of Indonesian Rice (Tons) \\
5 & DK & 34047.8 & 33947.8 & 100 & 0.29 & Requans \\
6 & DKPITA & 0.000171 & 0.000170 & 0.00 & 0.00 & Rice Demand Per Capita (Tons) \\
7 & MTH & 5621.1 & 6190.9 & -569.8 & -10.14 & Import From Thailand (Tons) \\
8 & MUSA & 3423.0 & 2762.0 & 661 & 19.31 & Import From America (Tons) \\
9 & MKIS & 1941.4 & 1941.4 & 0.00 & 0.00 & Import From Pakistan (Tons) \\
\hline
\end{tabular}

Source: Processed FAO's Data.

In the process of simulation analysis, the single price variable was implemented for the countries in the ASEAN this is due to the trend of unification in the region of AEC. Numerous results can be observed from the implementation, for example the decline in the use land for the purpose of harvest of up to 413.3 hectares, or $3.66 \%$. A decrease in productivity can also be seen by up to 51.95 tons / hectare, or down by 0.22 percent. The result of the simulation shows that price for crops decreased. The simulation shows that demand for rice has increased to 100 tons per year or by $12.29 \%$. The simulation also shows the same price of rice between Indonesia and Thailand, in which rice imported by Indonesia from Thailand decreased by 569.8 tons per year or 10.14 percent. On other hand, rice imported by Indonesia from America increased by 661 tons or 19.31\%. Rice imported from Pakistan did not seem to change.

The analysis of forecast conducted in this research, is with the intention to observe the prospect of the total imported rice from Thailand and Vietnam, as well as the price of rice in Indonesia, Thailand, and Vietnam throughout the year of 2014 to 2033.

Forecast of Rice Imported from Thailand from 2014-2033. The result of the forecast on rice import shows an increasing trend up till 2029, but a decline will happen on 2030 till 2033. The decline in rice imported from Thailand is about 3528.39 in 2033

MTH

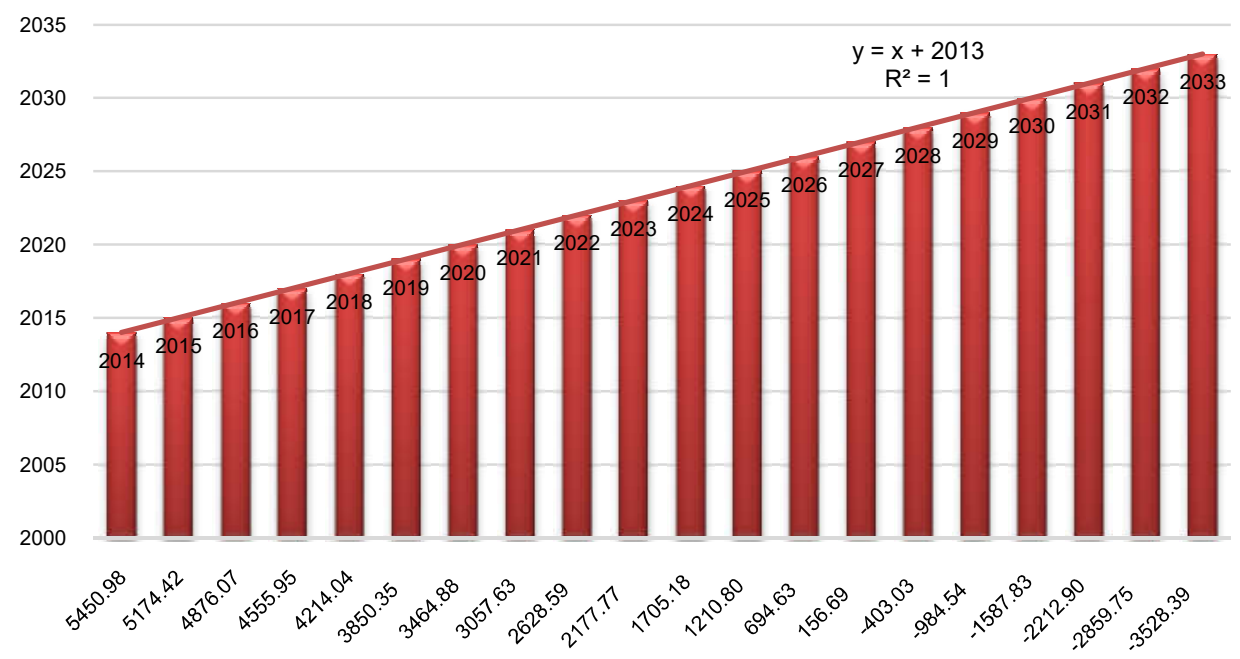

Figure 1 - Forecast of Rice Imported from Thailand from 2014 -2033

Forecast of Rice Imported from Vietnam from 2014-2033. Vietnam, being one of the world's largest rice producing country in the world should naturally be taken into account in the process. From the figure, it can be inferred that Indonesia will import more as years will come. 


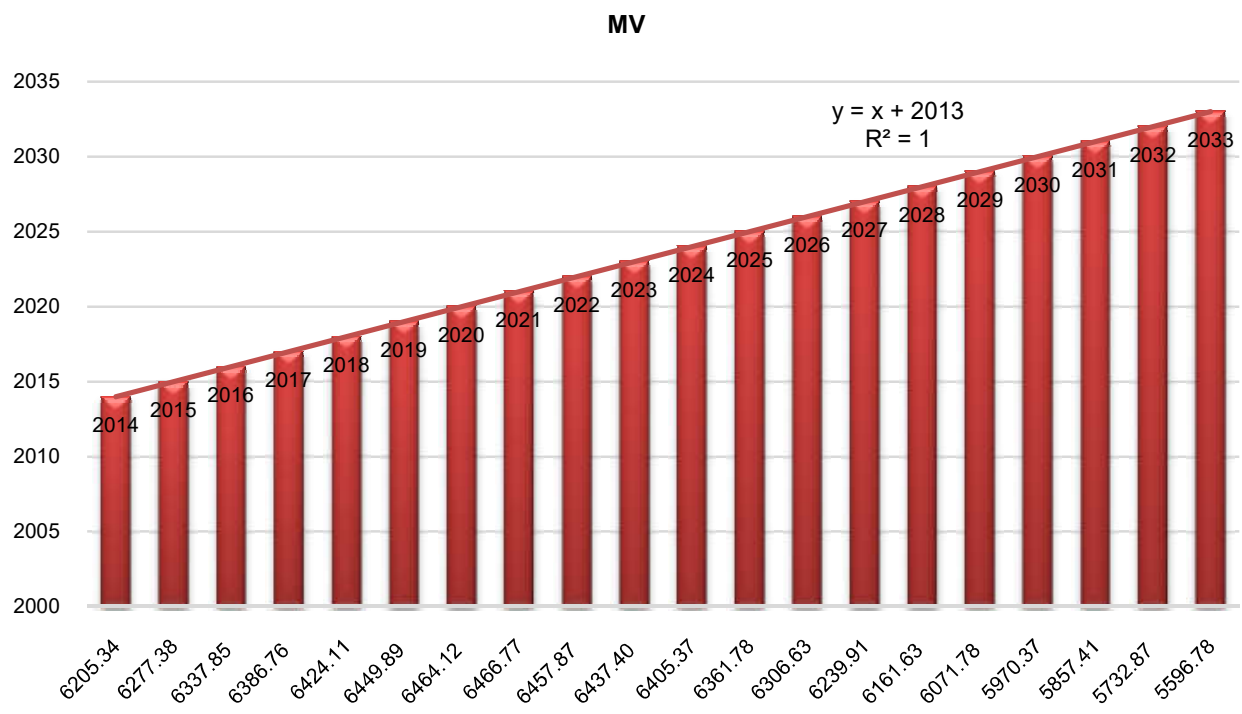

Figure 2 - Forecast of Rice Imported from Vietnam from 2014-2033

The result of the forecast on rice import shows an increasing trend up till 2033 but compared to the price of rice imported from Thailand of about 2282.62 dollars per tonne, 249.62 dollars per tonne more expensive. This can be one of the reasons that Indonesia decides to import its rice from Vietnam rather than Thailand.

Forecast of Thailand's Price of Rice from 2014-2033. Price is a deciding factor for Indonesia for choosing its import destination, therefore it is necessary to observe and understand the trend price for rice in the southeast Asia region. The price of rice from Thailand increases in 2033 by 2282.62 dollars per ton, 249.62 dollars per ton more expensive compared to the price of Vietnam's rice.

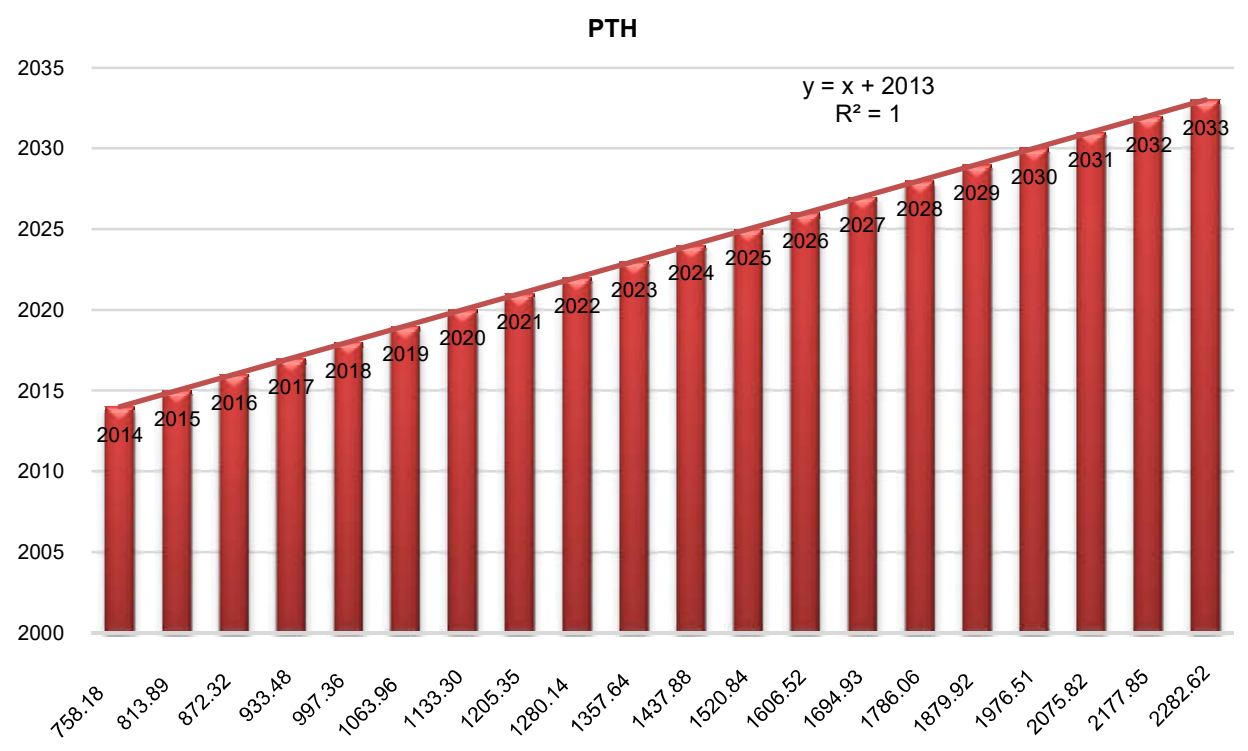

Figure 3 - Forecast of Thailand's Price of Rice from from 2014-2033

Forecast of Indonesia's Price of Rice from 2014-2033. Indonesia is the third amongst the list of the largest rice producing country in the world, in addition the result of the forecast also shows that the tendency for price increase is the highest amongst the other countries in the southeast Asia region. 
PB

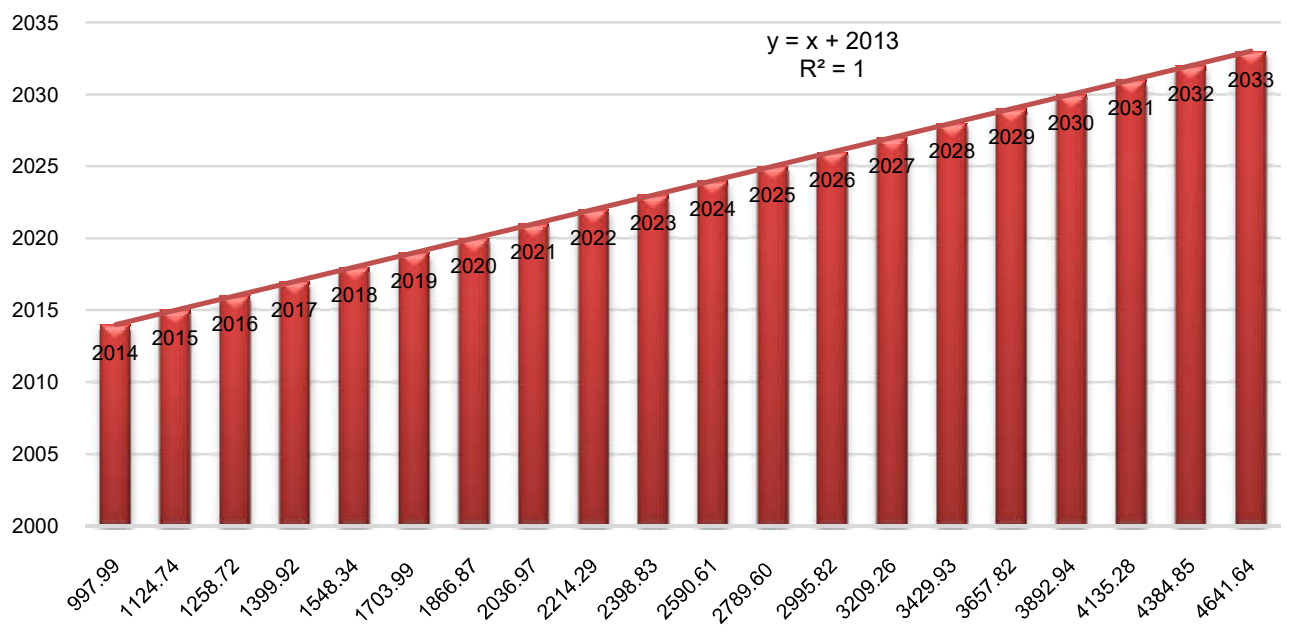

Figure 4 - Forecast of Indonesia's Price of Rice from 2014-2033

Indonesia's price of rice is higher compared to other countries such as Vietnam and Thailand, in 2033 it will reach the price of 4.641 .64 dollars per ton. 2359.02 dollars per tons more expensive compared when to the price of rice from Thailand and 3,755.44 dollars per tons more expensive compared to Vietnam's rice.

Forecast of Vietnam's Price of Rice from 2014-2033:

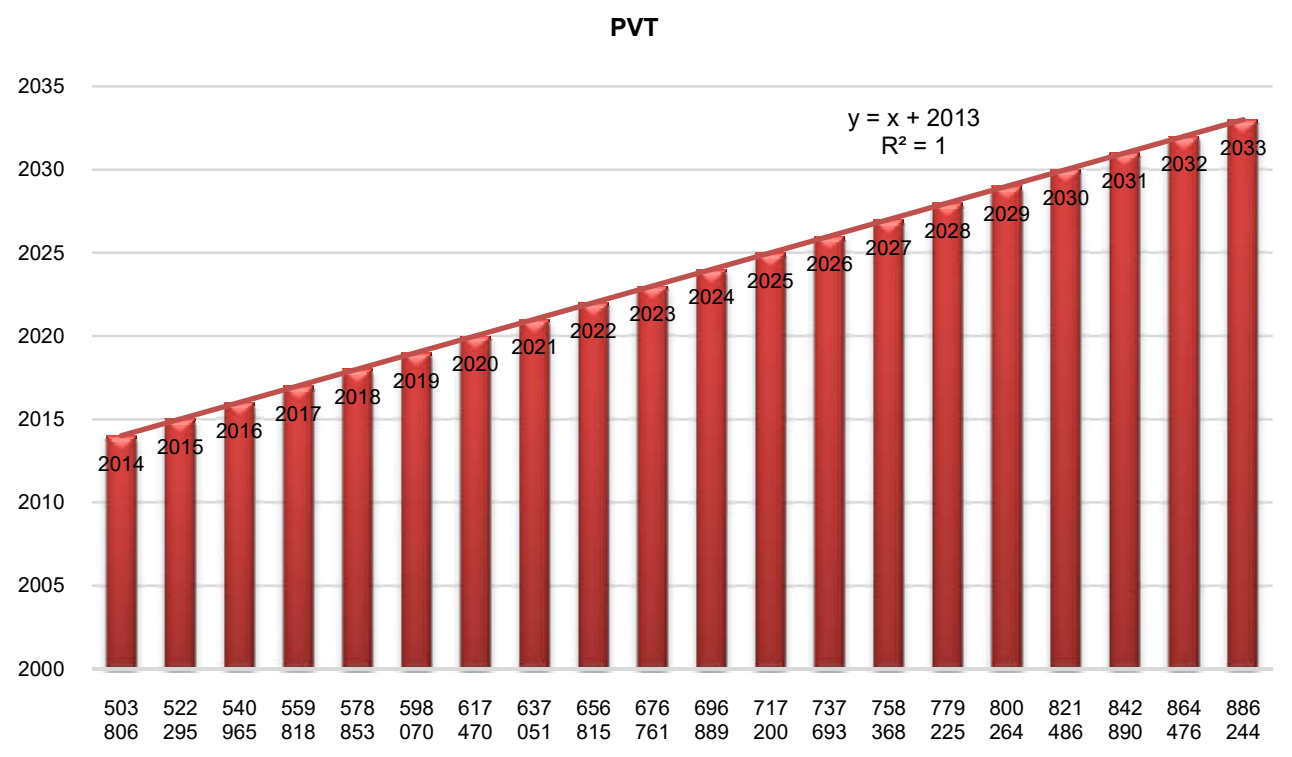

Figure 5 - Forecast of Vietnam's Price of Rice from 2014-2033

There seems to be an increase in the price of rice imported from Vietnam in 2033 that is 886.2 dollars per tons cheaper than the price of rice imported from Thailand that is 2282.62 dollars per tonne.

\section{DISCUSSION OF RESULTS}

The result of the simulation on the elimination of trade restriction on Thailand $(\mathrm{RTH}=0)$ due to the implementation of single price in ASEAN Economic Community (MEA), there is a change in the use of harvesting area in Indonesia which decrease to 413 hectares per year 
or decrease 3.66 percent. This is because there is a tendency with the elimination of restrictions within the ASEAN Economic Community (AEC), the Indonesian government is more likely to import of rice, import destination country of Indonesia rice is from Country Vietnam. As for the reason for the import of rice to Vietnam because the price of rice country of Vietnam more nuts ah compared to Thailand, on the trend in the use of agricultural land in Indonesia has over governance to the designation of non-agricultural, reinforced with $\mathrm{h}$ acyl forecasting import rice Indonesia to Vietnam has increased to with ta hun 2033.

From simulation analysis results in the single application environment ASEAN countries due to the incorporation of the countries in the ASEAN Economic Community (AEC), then there are some things that decrease cropland use covering an area of 413.3 hectares. Or $3.66 \%$. Productivity decreased by 51.95 tons / hectare. Or down 0.22 percent. Rice prices decreased. From the simulation found that demand for rice has increased 100 tons or increased 0.29 percent. With the same price of rice between Indonesia and Thailand, the import of Indonesian rice from Thailand decreased by 569.8 tons or 10:14 percent, but instead import rice Indonesia to the United States has increased throughout large 661 tons or 19:31 percent, this is strengthened by the results of forecasting, where Indonesian price rice was highest in 2033 in comparison with other countries such as Vietnam and Thailand, reaching 4,641.64 dollars per tons. More expensive 3.75 5.44 dollars perton when compared with the price of rice from Vietnam and more expensive of 2,359.02 dollars compared with Thailand.

\section{CONCLUSION}

The simulation on the elimination of Thailand's trade restriction $(\mathrm{RTH}=0)$ resulted in the decrease of the harvested area in Indonesia of about 413 hectares per year or by $3.66 \%$. The number of rice imported by Indonesia from Thailand is decreased to up to 623.1 ton per year.

Simulation $p$ Application of single price for the establishment of the ASEAN Economic Community (AEC), resulting in a decrease in the use of cropland area of 413.3 hectares. a tau $3.66 \%$. Productivity decreased by 51.95 tons / hectare. or down 0.22 percent. price rice has decreased, demand for rice has increased to 100 tons per year or an increase of 12:29 percent. Indonesian rice imports from Thailand decreased by 569.8 tons per year or 10.14 percent, but imports of Indonesian rice to the United States increased by 661 tons per year or 19.31 percent, respectively.

The result of forecast shows that there is an increasing trend of rice imported from Vietnam until the year 2033.

Indonesia's price of rice is the most expensive compared to other countries like Vietnam and Thailand, in the Year 2033 reached it reaches the price of 4.641 .64 dollars per tonne. 3755.44 dollars per tonne more expensive from Vietnam and 2,359.02 dollars per tonne compared to Thailand

Increasing the import price of rice from Vietnam until 2033 is 886.2 dollars per tonne cheaper than the import price of rice from Thailand country that is 2.282 .62 tons.

\section{REFERENCES}

1. 2000, Trade Block, Driver of Productivity Growth, World Bank Publication.

2. 2012, Thailand: Rice shippers mulling drastic measures, Asia News Monitor.

3. Achmad, Suryana dan Kariyasa, Ketut, "Ekonomi Padi Di Asia: Suatu Tinjauan Berbasis Kajian Komparatif" akses 3 september http://pse.litbang.pertanian.go.id/ind/pdffiles/FAE26-1b.pdf.

4. Acosta, Lilibeth A, Kagatsume, Masaru, ASEAN Rice Sektor in the WTO: Analysis of Demand and Supply in a Liberalized Trade Environment, ASEAN Economic Bulletin 20.3 Des 2003, 233-243. 
5. Akapaiboon, Natta. T, 2010, Trade liberalization, poverty and income distribution in Thailand: A computable general equilibrium-microsimulation analysis, The University of North Carolina at Chapel Hill, ProQuest Dissertations Publishing.

6. Akombe, Roselyn Kwamboka, 2005, Rutgers The State University of New Jersey Newark, ProQuest Dissertations Publishing,. 3170743.

7. Appleyard, Dennis R, Alfred, J. Field, JR and Steven L. Cobb. 2008. International Economics. Sixth edition. McGraw-Hill Company.

8. Aprilia Restuning Tunggal, 2013, IImu Hubungan Internasional, Politik, Ekonomi, Keamanan dan Isu Global kontemporer, Graha IImu, Yogyakarta.

9. Arianto, Nugroho Rony, "Tata Ulang Pola Pemasukan Beras Impor", akses 4 September 2015, http://bisniskeuangan.kompas.com.

10. Baskoro, Arya (Associate Researcher), http://crmsindonesia.org.

11. Nugroho, Agus Dwi, http://etd.repository.ugm.ac.id/ 5 sept 2015.

12. Bayu Krisnamurti,et al, 2014, Ekonomi Perberasan Indonesia, Perhimpunan Ekonomi Pertanian Indonesia (PERHEPI), Samudera Printing Jakarta.

13. Boediono, 1981, Ekonomi Internasional, Edisi ke 1, Seri Sinopsis Pengantar Ilmu Ekonomi No.3, BPFE, Yogyakarta.

14. Bordey, Flordeliza Hidalgo, 2010. The Impact of Research on Philipine Rice Productiona, University Of Ilinois At Urbana Champaign, Proquest Disertation Publishing 2010.

15. Baumol WJ dan AS Blinder. 2009. Economics Principles and Policy: Internasional Student edition.

16. Budi Winarno, 2010, Melawan Gurita Neoliberalisme, Erlangga, Yogyakarta.

17. Case KL, RC Fair and SM Oster. 2012. Prinsiples of Economics. Global Edition. Tenth Edition. Pearson Education Limited.

18. Charles $\mathrm{P}$ Kindeleberger, 1986, Ekonomi Internasional, saduran/ terjemahan oleh J. Bunardhi, Aksara baru, Jakarta.

19. Cramer, GL dan CW Jensen. 1994. Agricultural Economics and Agribusiness.Sixth Edition. John Wiley \& Sons, Inc.

20. Soesastro, Hadi. 2005. Accelerating ASEAN Economic Integration:Moving Beyond AFTA. Economics Working Paper Series. Paper presented at the Second ASEAN Leadership Forum. Kuala Lumpur, 17 March 2005.

21. Syafrial, 2006, Ekonomi Makro, Buku Ajar, Program Pasca Sarjana, Universitas Brawijaya Malang.

22. Sujarwo, 2005. Analisis Dampak Liberalisasi Perdagangan Terhadap Perubahan Perilaku Produksi, Harga dan Perdagangan Pupuk serta Komoditi Subsektor Pertanian Tanaman Pangan Indonesia. Tesis. Program Pascasarjana Fakultas Pertanian Universitas Brawijaya (tidak dipublikasikan).

23. Suvannaphakdy, Sithanonxay; Czerkawaski, Chris; Toyoda, Toshihisa. 2013, Potential Impact Of Region Trade Enlargement In East ASIA On Laos Trade, Journal of Economic Development 38.3 85-110.

24. Tambunan, T. 2004. Globalisasi dan Perdagangan Internasional.Ghalia Indonesia.

25. Tongzon, Jose L. Aug 2003, Us-Singapore Free Trade Agrement Implication For ASEAN: ASEAN Economic Bulletin 20.2 (Aug 2003): 174-178.

26. Tulus T.H. Tampubolon, Globalisasi dan Perdagangan Internasional. Ghalia Indonesia, Bogor.

27. Widyawati dan Setiawan, 2015, Jurnal sains dan seni ITS vol 4 no.1. Surabaya.

28. William Foster, Alberto Valdés, Agricultural incentives, growth and poverty in Latin America and the Caribbean, Jurnal, ECLAC Project Documents collection.

29. Zainuddin Djafar, et al, 2011, Ekonomi Politik Kemitraan ASEAN, Sebuah Potret Kerjasama, Pustaka Pelajar, Yogyakarta.

30. Yudi Ferrianta, Dampak Liberalisasi Perdagangan ASEAN-China Free Trade Area (ACFTA) Terhadap Kinerja Ekonomi Jagung di Indonesia, Disertasi, Universitas Brawijaya Malang. 